\title{
Pre-Recession Strategy for Survival and Growth
}

\author{
Mr. Shashank Kumar Srivastava, Member, IACSIT and IAENG
}

\begin{abstract}
In today's business scenario, threat of recession is already causing management to factor that possibility into their planning/budgeting processes. Many manufacturing sectors will struggle, if the experience of previous recessions holds true. Relatively low-technology manufacturing is likely to fare especially badly; highly internationalized; high-technology manufacturing is far better-positioned. The present forecast envisions a world recession that is somewhat shallower and shorter than many other forecasts. To avoid accusations of 'cuts' to jobs and services the government will have to push even harder for public service innovation to deliver high quality services at significantly lower cost. It's also very likely that a recession will impact outsourcing activity and practice. Even if you do manage to maintain your sales, your profit margins could still come down. You might have to devise new and innovative methods to attract customers towards your business. By implementing pre-recession strategy any organization can prevent or to minimize the loss from recession.
\end{abstract}

Index Terms-Recession, Threat of recession, Pre-Recession Strategy, Recession detection and recovery, prevention and avoidance

\section{INTRODUCTION}

Recessions are social and so political challenges as much as economic ones - a challenge of collective and collaborative adaptation to radically changed circumstances. Recessions associated with financial crises tend to be severe. The threat of recession is already causing management to factor that possibility into their planning/budgeting processes The more we can use the short term crisis to address and accelerate our adjustment to longer-term challenges, the better. These need to form part of a national economic strategy able to set long-term goals, and with the political credibility to help deliver them. Recession may prove to be a critical, creative turning point for the country. Recessions are never purely economic events. As businesses shed jobs, profits fall and investment is cut back so families find their main breadwinner looking for a job, communities see industries they have depended on contract and even disappear. Businesses are likely to respond to the recession by developing more intelligently networked forms of organization, accelerating shifts towards more open, networked approaches to corporate innovation. Preventing the financial crisis from reigniting will remain a pressing concern, even as attention turns to ameliorating the impact of the recession on the real economy. This report's main focus is not on crisis management, nor on the fiscal and monetary measures needed to counter recession. Many manufacturing sectors will struggle, if the experience of previous recessions

Sr. IT Faculty at SMU Pusa Road(e-mail: shashank.delhi@yahoo.com). holds true. Relatively low-technology manufacturing is likely to fare especially badly; highly internationalized; high-technology manufacturing is far better-positioned. The crisis will be a test of these regional coalitions. Only those built on a deep regional knowledge and strong leadership will succeed. With more public spending being diverted to tackle the recession there will be greater pressure on mainstream services. To avoid accusations of 'cuts' to jobs and services the government will have to push even harder for public service innovation to deliver high quality services at significantly lower cost. Recession is a time when hard choices can no longer be put off. Finland shows how such a strategy can be effective in leading the transformation of an economy through a period of crisis, encompassing business and civil society groups and mobilizing resources and initiative on a national scale. Because of the nearly universal pattern of falling growth in this global recession, it will be difficult for individual countries to export their way out of the slowdown. In the present global recession, some emerging-market economies may be able to achieve export growth as a consequence of the substantial currency depreciation that has already taken place. However, the contribution to recovery from exports seems likely to be modest because of the uniformly weak growth prospects of trading partners.

\section{PRior ANd Related Work}

The present forecast envisions a world recession that is somewhat shallower and shorter than many other forecasts. Unemployment is generally a lagging indicator. Its rise from a very low level to date is consistent with the employment data. However, for a variety of reasons, few companies, even those with the financial resources to do so, will actually put this learning into practice. When recession looms, most will reduce spending to shore up the bottom line. But even companies that can't (or won't) spend more can find ways to do more with less. A recession, therefore, can impose a discipline on marketing that is beneficial to brands in a variety of circumstances. Employees from for-profit firms are at greater risk of negative financial outcomes during the recession than those at nonprofits. Beyond these findings, there are fewer major differences than expected among employers with varying employee populations in how they are handling the recession, including those with more hourly employees or more unionized employees. The key to success during a downturn is maintaining focus. Keep your wits about you and focus on four things: your competition, your brand, your customers, and your communication. If you have a strong, successful brand, focus on what has worked for you so far. If your brand is in a relatively weak position, focus on 
systematically exploiting what strengths you have while addressing your weaknesses. During recessions, consumers and marketers alike must make the best of a bad situation. Not every brand will cut spending, but many of those that do will find themselves at a disadvantage when the recession ends.

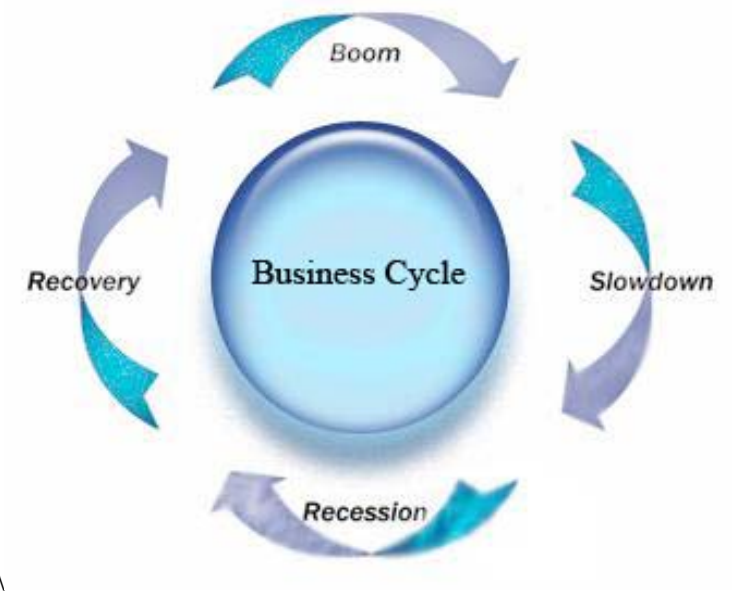

Fig: Economic/ Business Cycle

The current recession offers both threats and opportunities to nonprofits and the people they serve. Nonprofit organizations of all types face increasing demand for their services; yet resources are stretched thin due to the shrinking revenue base of many traditional funders. Participants gather information about how the recession could impact their programs, finances, and human resources. A typical Action Plan includes: statements tying your mission and values to program outcomes during the recession, projections on how the recession could affect your income, expenses, and programs, decisions about key programmatic elements that must be preserved, diminished, increased, eliminated or postponed until after the economic crisis has lessened, strategic decisions that need to be made by board and staff to move forward. Before Proceeding Recession, we need to know market economy. First is, two stages of market economy i.e. growing market economy and declining market economy; another one is two factors of market i.e. demand and supply. In growing market economy, stock market rises, investors believe trend will continue so value of stock increases. With more money investors buy more stocks and consume more goods and services. In declining market economy, in response to decreased demand producers lay off people and decrease consumption of raw materials, consumers do not feel confident about economy, so they buy less stuff. Investors fear the value of stock will decrease, so they are less willing to invest in new companies. Two factors of market; - demand and supply. Producer wants his demand always to be high and Consumer wants his buying cost always to be low. Recession is the economy shrinking for two consecutive quarters ( $=6$ months) with a decrease in the GDP Recession is a normal part of the business cycle; however, one-time crisis events can often trigger the onset of a recession. The term business cycle (or economic cycle) refers to economy-wide fluctuations in production or economic activity over several months or years. These fluctuations occur around a long-term growth trend, and typically involve shifts over time between periods of relatively rapid economic growth (expansion or boom), and periods of relative stagnation or decline (contraction lor recession). Business cycles are a type of fluctuation found in the aggregate economic activity of nations that organize their work mainly in business enterprises: a cycle consists of expansions occurring at about the same time in many economic activities, followed by similarly general recessions, contractions, and revivals which merge into the expansion phase of the next cycle; in duration, business cycles vary from more than one year to ten or twelve years; they are not divisible into shorter cycles of similar characteristics with amplitudes approximating their own. The economy goes through different cycles. One of them is recession. It is observed when the prices start to increase, the living standard starts to fall, unemployment rises, and businesses stop expanding. Economic recession is defined as a significant decline in the economic activity across a country, lasting longer than a few months. Normally, the recession is visible in real GDP growth, industrial production, wholesale-retail trade, real personal income, and employment. That means we need a strategy to attack the recession, not just to respond to it. Innovation- in business, communities and public services needs to be at the heart of that attack.

Most people surveyed indicate that we are already in a recession. Unfortunately, by strict economic definition, we usually find that we're in a recession only either after the fact or when it's nearly over. Regardless, it's worth noting that the impact of a recession will vary by region and by industry. It's also very likely that a recession will impact outsourcing activity and practice. Even if you do manage to maintain your sales, your profit margins could still come down. You might have to devise new and innovative methods to attract customers towards your business. Governments, development aid agencies, non-profits, in particular, can focus on a range of policies, starting by taking more seriously the reality of international remittances. While the mortgage crisis affected a small breadth of people, it was undoubtedly more severe on Hispanic immigrants. Reducing costs by cutting expenses with layoffs may be eminent but should be avoided unless absolutely necessary. As labor is the most expensive cost on the company's balance sheets, more often than not, office staff or employees may have to be laid off until the economy improves. Customer service should be maintained as high priority for the sustainability of the company during tough economic times. The fear of recession drives managers to cut costs, reduce sales expectations and retrench across the board - particularly when it comes to developing new products and services. When the economy is down, people look to different product categories to solve persistent needs, making trade-offs that reflect both conscious and unconscious decisions. This recession may be the ideal backdrop for experimenting with small changes that target big needs.

Now, we are offering you the concept of pre-recession strategies that should be implying in the organization. These strategies have basically four phases namely, recession detection and recovery, prevention from recession and avoidance. If we talk about recession detection, our 
organization can overcome recession by knowing that due to recession what kind of problems may occur for a particular organization and how much it affects to that organization? The one of the reason of economic slowdown which leads to recession is the blockage of cash flow in the market. There is a concept of mutual exclusion. Recession is the result of economic slowdown in the market. After detection of recession, next step is recovery process. Recovery is the stage where your organization recovers/overcome with the loss due to recession period and also through this strategy one can minimize the loss due to recession. In our next phase, i.e. recession prevention, here we are offering you a concept that there should be an electronic system that suggests the organization time to time the causes and different sources of loss occurred during the recession. It will also help and suggest to organization that what strategy should be adopted by the company to minimize the loss. This criterion is based on the cash-flow in the market. This electronic system keeps all records related to cash-flow in the market. And the last phase is recession avoidance. It is not necessary that every company in the market must be affected by recession. Such organizations are implying various strategies, so that they doesn't affected by the recession. Like cutting interest rates, tax cuts, increasing government spending etc which are already implemented by some organizations. Your organization can accept the minimum loss due to recession by avoiding it if it will not affect entirely. So, by pre-recession strategy, you can prevent your company by recession by implying the recession prevention strategies in your organization.

\section{CONCLUSION AND FURTHER WORK}

This recession may be the ideal backdrop for experimenting with small changes that target big needs. The fear of recession drives managers to cut costs, reduce sales expectations and retrench across the board - particularly when it comes to developing new products and services. Customer service should be maintained as high priority for the sustainability of the company during tough economic times. Most people surveyed indicate that we are already in a recession. It is observed when the prices start to increase, the living standard starts to fall, unemployment rises, and businesses stop expanding. That means we need a strategy to attack the recession, not just to respond to it. Innovation- in business, communities and public services - needs to be at the heart of that attack. So, by recession detection and recovery, prevention from recession and avoidance techniques we can prevent our organization from recession.

\section{ACKNOWLEDGEMENT}

I gratefully acknowledge the painstaking efforts of the editors and anonymous reviewers in helping make this paper more appropriate for the Management audience. I also appreciate the support and feedback of the Sikkim Manipal University Pusa Road Centre specially Mr. Sadhan Mukherjee and Mr. Sumanto Mukherjee and thankful to my colleague and other staff member of my department for their invaluable guidance and support during the paper.

\section{REFERENCE}

[1] Leitch Review of Skills (2006) 'Prosperity for All in the Global Economy - world class skills. Final report.' London: HM Treasury.

[2] Crowley, T. (1998) 'United Kingdom: Encouraging employer investment.' Geneva: ILO. vailable at: http://www.ilo.org/public/ English/employment/skills/ training/publ/uk.htm

[3] Department for Innovation, Universities and Skills (2008) 'Denham announces $£ 350 \mathrm{~m}$ to support small businesses.' 21 October 2008. London: DIUS.

[4] BusinessWeek (2008) 'MBA applications surge again.' 27 August 2008

[5] Safford, S. (2009) 'Why the Garden Club Couldn't Save Youngstown: the transformation of the rust belt.' Cambridge, MA: Harvard University Press.

[6] Poynter, G. (July 2008) 'The 'Credit Crunch' and London's economy.' London: University of East London.

[7] Benneworth, P. (2007) 'Regional leadership for innovation.' London: NESTA.

[8] NESTA (2008) 'UK global innovation - Engaging with new countries, regions and people.' London: NESTA.

[9] Levinson, N. S. and Asahi, M. (1995) Crossnational alliances and interorganizational learning. 'Organizational Dynamics.' Volume 24, Number 2, pp.50-63.

[10] Dunning, J. (2000) 'Regions, Globalization, and the Knowledge-Based Economy.' Oxford: Oxford University Press.

[11] NESTA (2008) 'UK global innovation - Engaging with new countries, regions and people.' London: NESTA.

[12] NESTA (2008) 'Innovation by Adoption: Measuring and mapping absorptive capacity in UK nations and regions.' London: NESTA.

[13] Leadbeater, C. and Cottam, H. (2007) 'The User-Generated State: public services 2.0.' Available at: http://www. charlesleadbeater.net/ archive/public-services-20.aspx

[14] Demos (2008) 'Making It Personal.' London: Demos.

[15] Mulgan, G. (2007) 'Ready or Not? Taking innovation in the public sector seriously.' London: NESTA.

About Author: Mr. Shashank Kumar Srivastava is associated with Sikkim Manipal University Pusa Road Centre in the capacity of Sr. IT Faculty since March 2008. He has worked as a 'Mandeya Lecturer' in the department of Computer Science, DDU Gorakhpur University from July 2003 to January 2008. He has done M.Sc. \& M.Phil. (Computer Science) and having more than 6 years teaching experience. He has presented more than 13 research papers in various National and International Conferences and two papers were published in International Journals. He is a member of IACSIT and IAENG. 